\title{
Valor religioso y literario de Fr. Gerundio de Campazas*
}

Quienes están sentimentalmente vinculados a Campazas, bien por haber nacido, bien por haber vivido su infancia, como es el caso del que hace esta presentación, en este pueblo del sur de la Provincia de León, tiene contraída con el P. Isla una deuda perenne de gratitud. Gracias a su famoso Fr. Gerundio el nombre de Campazas es conocido universalmente en los medios literarios. Fr. Gerundio es sin duda la obra literaria más importante en lengua española del siglo XVIII.

Bien es cierto que el Campazas de hoy se parece muy poco o nada al Campazas del tiempo de Fr. Gerundio, del que, como dice el P. Isla irónicamente, no hizo mención Tolomeo en sus cartas geográficas, y no lo hizo sencillamente porque no existía, o tal vez con mejor tino por su irrelevancia en la historia. El Campazas de hoy es un pueblo típico de la Tierra de Campos, campos góticos para más exactitud, con casas bien construidas y cómodas. Las gentes de este pueblo, sencillas, por sus costumbres, viven de uno de los oficios más antiguos del quehacer humano: la agricultura, apoyada en una pequeña ganadería. Tiene Campazas una hermosa iglesia, en la que el tiempo ha dejado su huella destructiva en algunos sectores de su exterior. Mas no le ha quitado nada de su esplendor interior. La iglesia tiene una bella cúpula con pinturas de cierto valor. Tiene cinco altares de estilo barroco, aunque sobrio y muy armónico. Sobresale, como es normal, el altar mayor, que ocupa todo el fondo de la misma iglesia, a cuyo conjunto están incorporadas las dos puertas de la sacristía, representando una de ellas el misterio de la Encarnación y la otra, el misterio de la Visitación. La sacristía tiene también

* Isla DE, J.F., Historia del famoso predicador Fray Gerundio de Campazas, Alias Zotes, Planeta, Barcelona 1991, 11 x 18,5, 712 p. 
su valor. Es amplia. Y debió tener en su tiempo diversas estatuas adosadas al techo de la misma. En su tiempo hubo órgano, del que no queda más que la cobertura. Se conserva una extraordinaria cruz procesional. Todo ello hace intuir que la iglesia de Campazas tuvo su importancia en tiempos pasados, hasta el extremo de existir los domingos y días de fiesta una misa de asistencia, como se decía entonces.

Apenas hay recuerdos relacionados con Fr. Gerundio. Tan sólo una casona, hoy derruida, de las típicas de Tierra de Campos, enfáticamente llamada la corte de Fr. Gerundio. Es posible que en este lugar existiera en tiempos en que el P. Isla correteaba por las calles de Valderas un convento y en él algún predicador famoso por sus extravagancias oratorias, dando así motivo al P. Isla para escribir su famoso Fr. Gerundio. Estamos, desde luego, en el campo de las hipótesis.

La obra del $\mathrm{P}$. Isla tiene muchos títulos para considerarse una obra única en su género. Y necesaria. La corrupción en que había caído la oratoria sagrada necesitaba de un revulsivo como el que ofrece el Fr. Gerundio. Sin llegar a la altura literaria del Quijote, bien se puede decir que lo que fue la obra genial de Cervantes para los amantes de los libros de caballería, eso fue la obra del P. Isla para los extravagantes predicadores. En este sentido el Fr. Gerundio consigue pleno éxito. Nadie como Isla ha ridiculizado las exageraciones de una oratoria que había perdido su rumbo. Isla estaba capacitado para ello. Poseía un gran ingenio. Y era además un gran predicador. Ingenio y erudición se conjugan maravillosamente en esta obra. De ahí que su lectura no resulte nada fácil. Resulta fácil ciertamente quedarse con lo llamativo, con lo que excita a la risa. Pero no resulta nada fácil seguir al autor en todo ese cúmulo de erudición que representa su obra.

Fr. Gerundio fue una obra controvertida desde sus orígenes. La primera parte tuvo un éxito editorial sin precedentes. Se agotó en pocos días. Pero pronto comenzaron las críticas. "Las acusaciones, se nos dice en la Introducción, se sucedían calificando a la obra, como es el caso de Cristóbal Manuel Jiménez, mercedario, «de malsonante, peligrosa, temeraria, arrogante, irreverente, escandalosa, impía, maldiciente, detractiva y denigrativa de las sagradas religiones y de los ministros de la iglesia»" (XI). Es difícil encontrar un elenco de adjetivos tan negativos como el que acabamos de escuchar. No faltan, como suele suceder en estos casos, las palabras laudatorias. "Jiménez no entiende cómo Montiano, contra quién va parte del ataque, pudo escribir que en la obra no hay «artículo malsonante, expresión infamatoria, concepto sin arrimo, ni consejo sin autoridad" (XI). El mundo, en el que se mueve el Fr. Gerundio, se agita y se revuelve. La cosa alcanza su punto más virulento, cuando la Inquisición toma cartas en el asunto. Se prohíbe la impresión de la 
segunda parte y la reimpresión de la primera. Isla es consciente del perjuicio que le viene encima. Sale a la palestra con diversos escritos en favor de su Fr. Gerundio. No tiene mucho éxito. Eso sí, advierte de un peligro, que luego se hace realidad. "Es de temer que los libreros extranjeros se aprovechen de esta ocasión para chuparnos nuestro dinero, interesándose ellos solos a costa de nuestros trabajos, sin que alcance providencia humana a embarazarlo, por el hambre que hay de tal libro dentro de España y fuera de ella" (XI-XII). En Bayona, en concreto, se hacen diversas ediciones del Fr. Gerundio que luego pasan clandestinamente a España. "Isla muestra su conciencia de autor maltratado, como, por otras razones hará después, en la conocida carta a su cuñado Nicolás Ayala, de 17 de noviembre de 1758, cuando dice: "Tú no sabes bien lo que a un hombre le cuesta ser autor. Tal vez mil veces necesita rendir su juicio al de un majadero, lo cual, creémelo, es un grandísimo trabajo" (XII). Habla bien claro del éxito de Fr. Gerundio en el extranjero Sempère. Dice: "Fuera de España ha sido sumamente celebrada la Historia del P. Isla" (III, 1786, 128 de su Biblioteca), y así extracta algunas opiniones como la del autor del Journal étranger de abril de 1970 o la del marqués de Caracciolo "sujeto bien conocido por su piedad y por su literatura", quien relaciona la novela con el Quijote. En Europa se hicieron numerosas traducciones y en Inglaterra se hizo una edición por suscripción pública. En España las ediciones piratas se multiplicaron, entrando muchas por San Sebastián tras haberse compuesto en Bayona. De estas ediciones dice Leandro Fernández de Moratín en el prólogo que escribió para una edición de Fr. Gerundio que quedó inédita: "Entretanto, la estimación que se hacía en España de esta obra iba aumentándose... Se leían, se celebraban en silencio los instructivos disparates del predicador de Campazas... Apoderándose (de la obra) los judíos de Bayona, y en pérfidas y atropelladas ediciones acabaron por destruirla; hízose objeto de sórdida especulación; los donaires del P. Isla, como género de contrabando, venían por sendas excusadas, en los cuévanos de las pasiegas, entre los botes de rapé y las muselinas" (III, 1868, 206-207)" (XII).

El Fr. Gerundio es una obra polémica en y desde su misma entraña. Es polémica, porque el Fr. Gerundio es, en el fondo, una crítica de una sociedad y de una iglesia en las que las formas grotescas del decir y los disparates tenían mucho eco. El doctor José Constancia Andino, a quien se había encomendado la crítica de la segunda parte, afirma: "la obra es una graciosa sátira seguida con arte contra los malos predicadores, y a paso reprende, en el mismo tono, las malas traducciones de libros extranjeros, especialmente franceses, que han introducido en nuestro idioma sus voces y frases, que 
hechos moda entre la gente de poca instrucción, le van desfigurando... El remedio de estos abusos es necesario" (XIII).

Recibida con entusiasmo por unos, rechazada con acritud por otros, la obra del P. Isla constituye un hito importante en la literatura española. No es una obra perfecta. No alcanza el nivel de la obra de Cervantes, con la que en ocasiones se ha querido comparar. Pero indiscutiblemente hay en ellas páginas que acreditan al P. Isla como un gran escritor. Para entenderlo nada mejor que traer aquí el retrato literario que el $\mathrm{P}$. Isla hace del padre de Fr. Gerundio. "Éste tal rico de Campazas, hermano del gimnasiarca, se llamaba Antón Zotes, familia arraigada en Campazas, pero extendida por todo el mundo, y tan fecundamente propagada, que no se hallará en todo el reino, provincia, ciudad, villa, aldea ni aún alquería, donde no hiervan los Zotes, como garbanzos en olla de potaje. Era Antón Zotes, como se ha dicho ya, un labrador de una mediana pasada; hombre de machorra, cecina y pan mediado los días ordinarios, con cebolla o puerro por postre; vaca y chorizo los días de fiesta; su torrezno corriente por almuerzo y cena, aunque ésta tal vez era un salpicón de vaca; despensa o aguapié, su bebida usual, menos cuando tenía en casa algún fraile, especialmente si era prelado, lector o algún gran supuesto de la orden, que entonces se sacaba a la mesa vino de Villamañán o del Páramo. El genio bondadoso en la corteza, pero en el fondo un si es no es suspicaz, envidioso, interesado y cuentero: en fin legítimo bonus vir de Campis. Su estatura mediana, pero fornido y repolludo; cabeza grande y redonda, frente estrecha, ojos pequeños, desiguales y algo taimados; guedejas rabicortas, a la usanza del Páramo, y no consistoriales como las de los xesmeros del campo de Salamanca; pestorejo, se supone, a la jeronimiana, rechoncho, colorado y con pliegues. Éste era el hombre interior y exterior del tío Antón Zotes, el cual, aunque había llegado hasta el banco de abajo de medianos con ánimo de ordenarse, porque dicen que le venía una capellanía de sangre en muriendo un tío suyo, arcipreste de Villaornate; pero al fin le puso pleito una moza del lugar, y se vio precisado a ir a la iglesia, mas no al coro y al altar, sino al santo matrimonio" (p. 65-66).

¿Quién va a dudar que nos encontramos ante un párrafo cargado de ingenio y buen decir? Éstas son las notas que, a mi parecer, recorren la mayoría de las páginas del Fr. Gerundio. Y ya que la obra es una ingeniosa parodia contra las grotescas exageraciones de los malos predicadores de entonces y de siempre, me parece oportuno recordar aquí parte del famoso sermón predicado por Fr. Gerundio en Campazas con motivo de la fiesta del Corpus. El P. Isla describe con lujo de detalles los antecedentes a un sermón de tanta trascendencia. Sería prolijo recordarlos aquí. Pero lo que no se puede omitir es lo que bien pudiera llamarse el cuerpo del sermón, es decir, 
la parte más importante del mismo. Nuestro Fr. Gerundio se halla en el púlpito. La iglesia, por supuesto, está abarrotada de gente ansiosa de escuchar a su hijo más preclaro. El predicador respira hondo y abarca con su mirada toda la asamblea. Y comienza su exposición, su magnífica exposición, según su entender. "O hay sacramento en Campazas, o no hay en la iglesia fe". Y comenta Isla: "Para tomar esta acertada determinación, tuvo buenas y legítimas razones; pues sobre ser aquella cláusula, sin disputa alguna, la más suspensiva y la más enfática de todas, era también la más verdadera, siendo indubitable que si en Campazas no había sacramento, supuesta la consagración, tampoco le habría en la iglesia de San Pedro, en Roma, ni en ninguna de toda la cristiandad, y allá iba la fe por esos trigos de Dios. Fuera de que esta cláusula le venía de perlas para el asunto que ya había resuelto tomar, conviene a saber, que Campazas era la patria nativa del Sacramento de la Eucaristía, lo que, a su modo de entender, estaba concluyentemente probado; porque, llevando como él llevaba, la opinión, y es en realidad la más probable, de que el verdadero y legítimo nombre de Campazas en su primitiva institución había sido Campazos, esto es "campos espaciosos y largos, campos muy dilatados", y consiguientemente que el lugar de Campazos fue, digámoslo así, como el tronco, como el fundador, o como el lugariarca de la frugífera región de Campos, a la cual dio glorioso y oportuno nombre. Supuesto todo esto, discurría nuestro Fr. Gerundio con tanta solidez como sutileza de esta manera:

-La materia remota del Sacramento de la Eucaristía es el trigo; la patria del trigo es Campos; la casa solariega de Campos es Campazas, luego Campazas es el solar y la patria del Santísimo Sacramento.

Esto por lo que toca a la materia del Sacramento en la especie del pan; vamos a la misma materia remota en la especie del vino. Sic argumentor: el vino es materia remota de la Eucaristía; el vino nace en las viñas; las viñas, en los campos; los campos, en Campazas, ergo, etc. Para la exornación no me sobra otra cosa que materiales tomados de la Escritura, de los Padres, de los expositores, de los autores profanos; y si me resuelvo a valerme de la fábula, también de los mitológicos" (412-413).

Se podría prolongar la cita. Pero lo referido es más que suficiente para darse una idea de cómo discurría el famoso sermón de Fr. Gerundio o, mejor, de cómo articulaba su contenido el íngenio del P. Isla.

Grandes y complicados son los problemas que la obra del P. Isla suscita a la hora de relacionarla con el género literario en que se enmarca: la novela. Porque eso es, ante todo, la famosa historia de Fr. Gerundio de Campazas. Una novela moderna que se nutre de la realidad social y quiere ser una crítica, en ocasiones audaz, de los malos predicadores que en el tiempo existían. 
El problema era grave. Y afectaba a un gremio importante de un estamento, la iglesia, que entonces tenía mucha fuerza. A ello se debe la fuerte oposición con que fue recibida y que, como suele suceder en estos casos, contribuyó de forma no pequeña a la fama de la misma. "La novela fue, pues, objeto de culto por parte de todos aquellos que anhelaban una reforma en la oratoria sagrada, pero también en un campo más amplio, de aquellos que pretendían una reforma de la educación y de otros planos de la sociedad" (Álvarez Barrientos, Introducción. XIV).

La crítica de la mala oratoria sagrada, que contiene el Fr. Gerundio, ha acaparado la atención tanto del lector como de los estudiosos. Y, si es verdad que su centro se halla ahí, también es verdad que el Fr. Gerundio tiene un campo de acción más grande. La reducción del campo de atención al campo de la oratoria sagrada conllevó graves inconvenientes. Uno de ellos, no pequeño por cierto, es el olvido de los aspectos literarios y novelísticos de la obra. "Pocas aproximaciones, se dice en la Introducción, se han hecho a Fr. Gerundio desde la perspectiva de la novela como género. Si salvamos algunas páginas de Sebold (1960), el artículo de Polt (1979) y últimamente Zavala (1987) el resto de la bibliografía gerundiana se la ha orientado hacia el tema de la oratoria" (XV).

Es el momento, pues, de referirse a las calidades literarias del Fr. Gerundio. Algo se indicó al respecto, cuando se hizo constancia de que el P. Isla es un gran escritor. Indicativo es también al respecto, lo que ha hecho la Editorial Planeta, incluyendo al Fr. Gerundio en la sección que ha dedicado a clásicos universales. Lo que habla por sí solo de la relevancia del P. Isla en la Literatura. Valga sobre el particular el recuerdo aquí de alguno de esos juicios hechos por quienes conocen a fondo la obra del P. Isla. "Nadie seguramente podrá negar a Isla fecundidad de ingenio, riqueza y amenidad de imaginación y gracia y hermosura de estilo. Tantos accidentes tan bien ideados y conducidos fácil y espontáneamente, tantas pinturas tan vivas y expresivas, tantos diálogos tan verdaderos y naturales, tantas expresiones tan propias y enérgicas y tantas otras prendas de invención y de estilo constituyen a Isla autor original, y nos dan en su historia de Fr. Gerundio un romance clásico y magistral" (XV-XVI).

Como novela, el Fr. Gerundio tiene sus lunares. Lunares que obedecen, entre otras cosas, al afán eminentemente didáctico del $\mathrm{P}$. Isla. El autor quiere acabar por medio de su obra con los predicadores barroquizantes de su tiempo. Y ello limita su horizonte de visión. "Isla, al contrario de Fielding que, como sabemos, también se sitúa en la estela de Cervantes, no da un paso adelante en la historia de la novela al estar excesivamente ligado a su intención didáctica. Su objetivo reformista le está limitando en el uso libre 
de los medios que puede emplear para construir su novela. Una y otra vez vuelve a la idea que quiere dejar clara, reiterando su mensaje reformador de la oratoria sagrada mediante discursos, sermones, reflexiones que lastran la novela. La forma narrativa no es libre para desarrollarse, sino que está el servicio de la intención didáctica" (XVI-XVII). En síntesis se puede afirmar "que Fr. Gerundio es una novela moderna o, que en todo caso, nace con esa intención. Pero tiene... un pesado lastre que la hace naufragar como tal: la demasiada fidelidad de su autor a un estrecho afán didáctico que le lleva a introducir grandes sermones... Todo este contenido, que seguramente ocupará la mitad o más de la novela, hace difícil, para un lector de hoy una lectura cómoda" (XVII). Cierto que la lectura del Fr. Gerundio no resulta cómoda. Gran parte de su mensaje, el que se refiere precisamente a la crítica irónica de los malos predicadores, es agua pasada. Con todo, hay que agradecer a la Editorial Planeta la buena idea de poner al servicio del público una obra que tiene mucho que enseñar.

Benito DOMÍNGUEZ

Estudio Teológico Agustiniano Valladolid 